\title{
The Role Of Doctors And Nurses In Hiv/Aids Handling Efforts Of The Gays.
}

\author{
Peran Dokter Dan Perawat Dalam Menanggulangi Hiv/Aids Pada Kaum Gay \\ Di Kota Semarang \\ Ludgardis Ramni; Agnes Widanti and Hadi Sulistiyanto \\ email: diskagardis@gmail.com \\ Master of Law Science \\ Concentration of Health Law \\ Soegijapranata Catholic University of Semarang
}

\begin{abstract}
Health was one of the important and main elements in improving community's welfare. Doctors and nurses were part of health workers providing health services to the community to improve their health status, including in HIV/AIDS handling efforts. Gays were homosexuals who were closely related to HIV/AIDS. HIV prevalence of gays in Semarang city was 12\%. Doctors and nurses were health workers who had an important role in HIV/AIDS handling efforts. The objective of this study was to see the role of doctors and nurses in HIV/AIDS handling efforts of the gays.
\end{abstract}

This research applied a socio-legal approach and analytical descriptive specification. This research used primary and secondary data. The primary data were gathered through interviews and field observation. The informants were eight members of gay community while the other informants were the head of the community beside doctors and nurses of Halmahera Health Center. The secondary data were obtained through literature studies particularly having relation with the role of doctors and nurses in handling HIV/AIDS to the gays. The data were then qualitatively analyzed.

The results of the study showed that the doctors and nurses had well accomplished their role in handling HIV/AIDS for the gays but it had not been accomplished in accordance with the provisions of the existing legislation. In handling HIV/AIDS to gays, a doctor had a role as a care provider, a decision maker and a communicator of the actions that should be given to the patients, while a nurse had a role as a care giver and a counsellor by providing diagnoses and appropriate nursing care to the patients as needed. The supporting factors were the availability of health facilities, health resources and adequate infrastructure whereas the inhibiting factors were lack of health personnel as a counselor and lack of self-disclosure of the gays

Keywords: the role of doctors and nurses, HIV/AIDS, gays

\section{Latar Belakang}

Kesehatan merupakan salah satu unsur penting dan merupakan unsur pokok dalam meningkatkan kesejahteraan masyarakat suatu negara. Menurut undang-undang nomor 36 tahun 2009 tentang kesehatan, Kesehatan adalah keadaan sehat, baik secara fisik, mental, spiritual maupun sosial yang memungkinkan setiap orang untuk 
hidup produktif secara sosial dan ekonomis. Untuk mewujudkan suatu taraf kesehatan, maka dibutuhkan suatu pembangunan kesehatan. Pembangunan kesehatan harus dilaksanakan oleh berbagai pihak bukan hanya dari pihak pemerintah saja tetapi juga pihak swasta, serta perlunya dukungan dari masyarakat agar pembangunan kesehatan dapat berjalan dengan lancar. Selain itu dukungan dari para tenaga kesehatan juga tak kalah penting, karena tenaga kesehatan merupakan kunci utama dalam keberhasilan pencapaian tujuan pembangunan kesehatan.

Tenaga Kesehatan yang dimaksud dalam penelitian ini adalah dokter dan perawat. Dokter dan Perawat merupakan bagian dari tenaga kesehatan sebagaimana dicantumkan dalam pasal 11 ayat 1 Undang-Undang Nomor 36 tahun 2014 tentang Tenaga Kesehatan. Dokter dan perawat merupakan orang pertama berkontak dengan pasien yang akan mendengarkan segala keluhan serta masalah kesehatan yang sedang dialami atau dirasakan. Dokter dan Perawat merupakan tenaga kesehatan yang bukan hanya memberikan pelayanan pengobatan kepada para pasien, tetapi juga memberikan pelayanan kesehatan yang berkaitan dengan pencegahan dan penaggulangan penyakit termasuk penyakit menular seksual seperti HIV/AIDS.

HIV adalah singkatan dari "human immunodeficiency virus", adalah virus penyebab AIDS (acquired immunodeficiency syndrome). HIV atau human immunodeficiency virus adalah virus yang menyerang sel darah putih dalam tubuh yang menyebabkan turunnya kekebalan tubuh pada manusia. Orang yang dalam darahnya terdapat virus HIV tampak sehat dan belum membutuhkan pengobatan. AIDS atau acquiired immunodeficiency syndrome adalah sekumpulan gejala penyakit yang timbul karena turunnya kekebalan tubuh. Akibat menurunnya sistem kekebalan tubuh akibat virus HIV maka seseorang mudah sekali untuk terserang penyakit seperti TBC, Kandidiasis, berbagai radang kulit, paru, saluran pencernaan, otak dan kanker. Stadium AIDS membutuhkan pengobatan antiretroviral (ARV) untuk menurunkan jumlah virus HIV dalam tubuh sehingga bisa sehat kembali. ${ }^{1}$ Di Indonesia pertama kali melaporkan adanya kasus AIDS pada tahun 1987 yaitu ditemukan seorang wisatawan Belanda yang terkena serangan PCP (Pneumocystis Carinii Pneumonia) yang kemudia meninggal di RSUD Sanglah Denpasar. Sejak pertama kali ditemukan pada tahun 1987 sampai maret 2017, laporan mengenai HIV/AIDS sudah menyebar di 407 (80\%) dari 507 kabupaten/Kota di seluruh Provinsi di Indonesia. Laporan kasus HIV/AIDS pada tahun 2016 sebanyak 198.219 orang yang terinfeksi HIV. laporan kasus HIV per tahun sampai dengan Maret 2017 bahwa ada sekitar 242, 699 orang yang terinfeksi HIV dan ada sekitar 87.454 orang yang terkena AIDS. ${ }^{2}$

Kota Semarang kasus HIV/AIDS pada tahun 2015 mencapai angka 2763 dan merupakan urutan pertama di provinsi Jawa Tengah, sedang provinsi Jawa Tengah sendiri menduduki pringkat ke empat dari jumlah seluruh provinsi yang ada di Indonesia. ${ }^{3}$ Dan pada tahun 2017 kasus HIV di kota Semarang mencapai angka 4.413. ${ }^{4}$ Kasus HIV/AIDS

\footnotetext{
1, www.aidsindonesia.or.id, Komisi Penangulangan HIV/AIDS Indonesia, diakses tanggal 16 oktober 2017

${ }^{2}$ www.aidsindonesia,or.id, Laporan Perkembangan HIV-AIDS dan penyakit Infeksi Menular Seksual Triwulan 1 tahun 2017, diakses tanggal 16 oktober 2016

${ }^{3}$ Komisi Penangggulangan AIDS Pusat Jawa Tengah, Kondisi HIV dan AIDS di Jawa Tengah 1993 s/d September 2015

${ }^{4}$ Dinas Kesehatan Kota Semarang, kumulatif kasus HIV Tahun 1995-2017.
} 
seperti fenomena gunung es dimana hanya tampak dipuncaknya saja, pada hal banyak sekali kasusnya tetapi hanya sedikit saja yang melapor kepada petugas kesehatan.

HIV/AIDS tidak hanya menyerang pada pasangan suami istri, anak-anak, remaja, para pekerja seks tetapi HIV/AIDS juga menyerang para kaum homoseksual seperti kaum Gay. Homoseksual merupakan keterarikan seksual berupa disorientasi pada pasangan seksualnya. Istilah Gay adalah suatu istilah yang digunakan untuk merujuk kepada pria homoseksual. Sedang Lesbian adalah suatu istilah yang digunakan untuk merujuk kepada wanita homoseks. ${ }^{5}$ Gay adalah istilah untuk laki-laki yang memiliki kecendrungan seksual kepada sesama pria baik secara fisik, seksual, emosional, atau secara spiritual. Kaum Gay mengacu pada tiga aspek, yaitu orientasi seksual, perilaku seksual dan identitas seksual. ${ }^{6}$ Di Indonesia kaum Gay sampai saat ini masih di tolak di kalangan masyarakat, hal ini dikarenakan bertentangan dengan etika dan moral, serta bertentangan dengan agama. Para kaum Gay acap kali sering mengalami diskriminasi oleh berbagai kalangan di masyarakat. Meskipun demikian para kaum Gay tetap bersemangat dalam memperjuangan hak-hak mereka agar bebas dari segala bentuk diskriminasi.

Jumlah kaum Gay di Indonesia sangatlah banyak, data Yayasan Mitra Indonesia pada tahun 2013 menunjukkan sekitar 3 juta jiwa populasi pria di Indonesia adalah Gay dan di prediksi meningkat setiap tahunnya. Data dari Komunitas Gessang (Gerakan Sosial Advokasi dan HAM untuk Gay) jumlah Gay di Jawa Tengah diperkirankan 114.400 orang pada 2010 dan meningkat sekitar 150.770 pada tahun 2015. Untuk kota Semarang hampir mencapai 17.254 orang pada september 2015. ${ }^{7}$ Kaum Gay sangat erat kaitannya dengan HIV/AIDS. Kasus pertama yang dilaporkan oleh Pusat Pengendalian Pengakit (CDC/Center For Disease Control And Prevention) di Amerika pada tahun 1981 menyatakan bahwa kasus HIV terjadi pada pria homoseksual. Data dari Dinas Kesehatan Kota Semarang pada tahun 2017 menunjukkan kasus HIV lebih banyak diderita oleh laki-laki yaitu $57 \%$ dibandingkan dengan perempuan yaitu $43 \%$. Kasus kaum Gay yang terinfeksi HIV/AIDS terus meningkat. Sesuai dengan data yang didapat prevalensi HIV pada kelompok Lekaki Seks Lelaki (LSL) yaitu $12 \%{ }^{8}$ Hal ini sesuai dengan hasil Surveilans Terpadu Biologis dan Perilaku (STBP) tahun 2011 yang menemukan peningkatan prevalensi HIV pada pada kelompok Lelaki Seks Laki (LSL) yaitu dari 5\% menjadi $12 \%$. Pada sebagian besar kasus HIV/AIDS, kaum Gay atau LSL tetap menempati peringkat kedua setelah hubungan seks pada heteroseksual. Survei Terpadu Biologis dan Perilaku (STBP) tahun 2014 yang dilakukan dikota Semarang terdapat 249 orang komunitas Gay didapatkan hasil bahwa $20.8 \%$ dinyatakan positif HIV.

Perilaku seksual berisiko HIV/AIDS yang dilakukan oleh kaum Gay meliputi oral dan anal karena memungkinkan terjadinya pertukaran cairan kelamin. Seksualitas pada kaum Gay juga terdiri dari tiga bentuk antara lain a). Orientasi seksual yaitu ketertarikan

\footnotetext{
${ }^{5}$ Nana Noviana, Konsep HIV/AIDS Seksualitas dan Kesehatan Reproduksi,Jakarta: Trans Info Media, 2016, hlm.40

${ }^{6}$ Susan Wira Anggraeni, Perilaku dan Gaya Hidup Komunitas Gay, 2013, http://digilib.unila.ac.id/269/ diakses tanggal 28 Oktober 2017

${ }^{7}$ Nirmala Herlani, Emmy Riyanti, Bagoes Widjanarko:, Gambaran Perilaku Seksual Berisiko HIV/AIS Pada Pasangan Gay, 2016, Jurnal Kesehatan Masyarakat Volume 4, No. 3, Juli 2016 ${ }^{8}$ Dinas Kesehatan Kota Semarang, Kumulatif Kasus HIV tahun 2007-2017 (Laporan Klinik KTHIV) di Kota Semarang berdasarkan kelompok resiko
} 
kepada sesama jenis. b). Perilaku seksual yaitu pelampiasan hasrat dan nafsu kepada sesama jenis yang berhubungan fungsi reproduksi,dan. c).Identitas seksual yaitu apa yang orang lain katakan yang berkaitan dengan orientasi seksual dan perilaku seksual. ${ }^{9}$ Di Indonesia memang belum ada peraturan khusus mengenai kaum Gay, namun seperti warga Indonesia pada umumnya secara hukum mereka masih dilindungi oleh UndangUndang dan peraturan-peraturan yang lain. Seperti yang tertuang didalam UndangUndang Kesehatan nomor 36 tahun 2009 yang menyatakan secara jelas bahwa setiap orang berhak atas kesehatan. Ini berarti kaum Gay berhak untuk mendapatkan pelayanan kesehatan yang terpadu termasuk dalam hal penangulangan HIV/AIDS.

Dalam melaksanakan penanggulangan HIV/AIDS pada kaum Gay sangat dibutuhkan peran dari tenaga kesehatan. Pada penelitian ini yang dimaksud dengan tenaga kesehatan adalah dokter dan perawat. Namun, pada kenyataannya upaya penanggulangan HIV/AIDS pada kaum Gay oleh dokter dan perawat belum dilaksanakan dengan baik. Hal ini ditandai dengan masih adanya kaum gay yang terinfeksi HIV/AIDS.

\section{Perumusan Masalah}

Berdasarkan uraian latar belakang diatas, maka dalam penelitian tesis ini dapat dibuat perumusan masalah, yaitu sebagai berikut:

1. Bagaimana Peraturan Tentang Peran Dokter dan Perawat dalam Menanggulangi HIV/AIDS pada Kaum Gay di kota Semarang?

2. Bagaimana Pelaksanaan Peran Dokter dan Perawat dalam Menanggulangi HIV/AIDS pada Kaum Gay di kota Semarang?

3. Faktor-Faktor apa saja yang mempengaruhi implementasi peran Dokter dan Perawat dalam Menaggulang HIV/AIDS pada Kaum Gay di kota Semarang?

\section{Metode Penelitian}

Metode penelitian yang digunakan dalam penelitian ini adalah yuridis sosiologis. Aspek yuridis dalam penelitian ini adalah peraturan perundang-undangan yang berkaitan dengan Penanggulangan HIV/AIDS pada Kaum Gay, peraturan tentang dokter, dan peraturan tentang perawat, sedangkan aspek sosiologis dalam penelitian ini adalah peran dokter dan perawat dalam penanggulangan HIV/AIDS pada kaum Gay. Dengan spesifikasi pendekatan adalah deskriptif analitik. Metode pengambilan data dalam penelitian ini adalah studi lapangan dan studi kepustakaan. Studi langan dilakukan dengan wawancara kepada anggota komunitas gay, dokter dan perawat di Puskesmas Halmahera, dan observasi dilakukan dilakukan di Puskesmas Halmahera terkait dengan kegiatan VCT. Analisa yang penelitian yang digunakan adalah analisa kualitatif. Fokus penelitian terletak pada peran dokter dan perawat dalammenanggulangi HIV/AIDS pada kaum Gay di Kota Semarang

${ }^{9}$ Nirmala Herlani, Emmy Riyanti, Bagoes Widjanarko, Op.Cit 


\section{Pembahasan Penelitian}

\section{Peraturan tentang peran dokter dan perawat dalam menanggulangi HIV/AIDS pada Kaum Gay.}

Di negara kita tidak terdapat regulasi atau peraturan mengenai Gay, hal ini di karenakan kaum Gay tidak diterima kehadirannya di masyarakat, karena sangat bertentangan dengan moral dan etika. Selain itu bertentangan dengan nilai-nilai sosial keagamaan. Kaum Gay acap kali mendapatkan diskriminasi dari masyarakat termasuk dalam memperoleh pelayanan kesehatan. Kaum gay perlu mendapatkan perlindungan terkait dengan hak asasi mereka sebagai manusia namun bukan perilakunya, dan sebagai warga Negara Indonesia mereka berhak untuk mendapatkan perlakuan yang adil dan bebas dari diskrimininasi, sebagaimana dicantumkan dalam Undang-Undang Dasar 1945 pasal $28 \mathrm{~h}$ ayat (2) yang menyatakan bahwa" setiap orang berhak mendapatkan kemudahan dan perlakuan khusus untuk memperoleh kesempatan dan manfaat yang sama guna mencapai persamaan dan keadilan". selain itu juga terdapat dalam dan pasal 4 Undang-Undang Nomor 39 tahun 1999 tentang Hak Asasi Manusia. Hukum berfungsi sebagai sarana untuk mewujudkan keadilan sosial dengan memberikan kebebasan terhadap setiap orang termasuk kaum gay untuk memperoleh kesempatan yang sama dalam mewujudkan persamaan tanpa adanya diskriminasi.

Kesehatan merupakan bagian dari hak asasi manusia, dan setiap orang berhak untuk mendapatkan akses dipelayanan kesehatan. Hak untuk mendapatkan akses di dipelayanan kesehatan tercantum dalam pasal 5 undang-undang nomor 36 tahun 2009 tentang kesehatan. Kaum Gay pun berhak untuk mendapatkan akses dibidang pelayanan kesehatan, khusunya terkait dengan HIV/AIDS tanpa adanya diskriminasi dari berbagai pihak. Dalam hal ini terdapat nilai keadilan, dimana hukum harus berlaku adil bagi setiap orang termasuk bagi kaum gay untuk mendapatkan akses bidang pelayanan kesehatan.

Pemenuhan hak pasien dalam pelayanan kesehatan termasuk didalamnya adalah kaum gay tercantum dalam pasal 52 Undang-Undang Nomor 29 tahun 2004 tentang Praktik Kedokteran, dan pasal 38 Undang-Undang Nomor 38 tahun 2014 tentang Keperawatan. Dalam memberikan pelayanan kesehatan termasuk pada kaum gay dokter dan perawat, senantiasa mematuhi hak-hak yang dimiliki pasien, karena hak pasien merupakan hak asasi yang wajib dipenuhi. Selain itu hubungan antara tenaga kesehatan dalam hal ini adalah dokter dan perawat dengan pasien merupakan hubungan hukum.

pasal 62 ayat (1) Undang-Undang Nomor 36 tahun 2014 tentang Tenaga Kesehatan. Pelayanan kesehatan yang diberikan oleh dokter dan perawat termasuk dalam upaya penanggulang HIV/AIDS pada kaum gay. Sebagai tenaga kesehatan dokter dan perawat memiliki kewajiban dalam memberi pelayanan kesehatan yang bermutu bagi pasien serta sesuai dengan standar operasional prosedur yang sudah ditentukan. Upaya kesehatan adalah setiap kegiatan dan/atau serangkaian kegiatan yang dilakukan secara terpadu dan berkesinambungan untuk memilihara dan meningkatkan derajat kesehatan masyarakat dalam bentuk pencegahan penyakit, peningkatan kesehatan, pengobatan penyakit dan pemulihan kesehatan. Upaya penanggulangan HIV/AIDS ini termasuk HIV/AIDS pada kaum Gay meliputi upaya promotif, preventif, kuratif dan rehabilitatif. Secara spesifik upaya penanggulangan HIV/AIDS ini termasuk HIV/AIDS 
pada kaum gay diatur dalam pasal 1 butir satu Peraturan Menteri Kesehatan Nomor 21 tahun 2013 tentang Penaggulangan HIV dan AIDS.

Konseling dan tes HIV adalah salah satu upaya yang dilakukan dalam menanggulangi HIV/AIDS termasuk HIV/AIDS pada kaum Gay, tujuan dari konseling dan tes HIV ini untuk mendetesksi sedini mungkin apakah seseorang terinfeksi HIV/AIDS atau tidak, serta konseling dan tes HIV harus dilakukan disemua fasilitas kesehatan, sebagaimana dicantumkan dalam pasal 2 dan pasal 6 Peraturan Menteri Kesehatan nomor 74 tahun 2014 Tentang Pelaksanaan Konseling Dan Tes HIV. Dalam melakukan upaya penanggulangan HIV/AIDS ini termasuk pada kaum Gay sangat dibutuhkan peran pemerintah sebagai pembuat kebijakan, agar semua program yang sudah dibuat dapat dilaksanakan dengan baik sehingga mendapatkan hasil yang diharapkan,sebagaimana terkandung dalam Pasal 2 Peraturan Daerah Kota Semarang nomor 4 tahun 2013 Tentang Penaggulangan HIV Dan AIDS.

Dari peraturan-peraturan yang ada terdapat nilai keadilan, kemanfaatan hukum dan kepastian hukum. Nilai keadilan dalam peraturan ini terkait dengan pemenuhan hak kesehatan kaum gay dalam mendapatkan akses pelayanan kesehatan tanda adanya diskrimininasi. Nilai kemanfaatan dalam regulasi ini terkait dengan upaya penanggulangan HIV/AIDS termasuk pada kaum gay adalah untuk menurunkan dan meniadakan infeksi baru, serta untuk menurunkan hingga meniadakan kematian yang disebabkan oleh HIV/AIDS serta dapat meningkatkan kualitas hidup dari mereka yang terinfeksi HIV/AIDS.

Nilai kepastian hukum dalam regulasi ini yang berkaitan dengan upaya penaggulangan HIV/AIDS khususnya pada kaum gay adalah hukum merujuk pada jaminan terhadap hak bagi kaum Gay. Artinya dengan kepastian hukum, hukum yang berisi keadilan, dan norma-norma yang memajukan kebaikan benar-benar berfungsi sebagai peraturan yang benar-benar ditaati.

\section{Pelaksanaan peran Dokter dan Perawat dalam menanggulangi HIV/AIDS pada Kaum Gay}

Sebagai tenaga kesehatan Dokter dan perawat memiliki peran yang sangat penting dalam meningkatkan kesejahteraan masyarakat dibidang kesehatan melalui pembangunan kesehatan. Pembangunan kesehatan merupakan bagian dari pembangunan nasional yang bertujuan meningkatkan kesadaran, kemauan, dan kemampuan hidup sehat setiap orang agar terwujud derajat kesehatan masyarakat yang setingginya.

Profesi dokter adalah suatu pekerjaan kedokteran yang dilaksanakan berdasarkan suatu keilmuan, kompetensi yang diperoleh melalui pendidikan yang berjenjang dan kode etik yang bersifat melayani. ${ }^{10}$ Dalam menjalankan profesinya, dokter memiliki peran yang penting dalam melakukan upaya kesehatan, termasuk dalam upaya penaggulangan HIV/AIDS pada kaum Gay. Peran dokter dalam pelayanan kesehatan ada tujuh (seven stars doctor/dokter bintang tujuh) yang meliputi Dokter sebagai care provider, Dokter sebagai decision maker, Dokter sebagai comunicator, Dokter sebagai comunity leader, Dokter sebagai manager, Reseacher, Faith and Piety.

${ }^{10}$ Momon,Sudarma, Op.Cit, hlm.74 
Upaya penanggulangan HIV/AIDS oleh dokter pada kaum Gay yang belum terinfeksi HIV/AIDS, meliputi upaya preventif berupa pencegahan terhadap masalah kesehatan atau penyakit. Bagi kaum gay yang hasil tesnya negatif untuk mempertahankan hubungan seks yang aman dengan setia pada pasangan dan menggunakan pengaman saat berhubungan seksual, serta dianjurkan untuk tetap melakukan VCT. Sedangkan upaya penaggulangan HIV/AIDS oleh dokter terhadap kaum Gay yang positif HIV, dokter menindak lanjuti yaitu dengan melakukan pemeriksaan lanjutan serta diberi terapi ARV sesuai dengan kebutuhan pasien. Upaya yang dilakukan kepada anggota komunitas yang terinfeksi HIV/AIDS lebih ke upaya kuratif dan rehabilitatif.

Perawat merupakan salah satu komponen yang penting dalam pelaksanaan layanan kesehatan, termasuk dalam upaya penanggulangan HIV/AIDS pada kaum Gay. Kegiatan yang dilakukan dalam upaya mencapai peningkatan kesehatan, pencegahan penyakit, penyembuhan, pemulihan dan pemeliharaan kesehatan dengan penekatan pada upaya pelayanan kesehatan primer, yaitu untuk memungkinkan setiap penduduk/individu mencapai kemampuan untuk hidup sehat dan produktif. ${ }^{11}$ Dalam menjalankan tugasnya, termasuk dalam melakukan upaya penaggulangan HIV/AIDS perawat memiliki fungsi yang diantaranya adalah mengkaji kebutuhan dan masalah kesehatan, menyususun diagnosis keperawatan, menyusun rencana asuhan keperawatan, melakukan tindakan asuhan keperawatan, melakukan evaluasi terhadap asuhan keperawatan.

Dari hasil penelitaian yang saya lakukan di Puskesmas Halmahera terkait dengan peran dokter dan perawat dalam menanggulangi HIV/AIDS pada kaum Gay. Upaya yang dilakukan oleh dokter dan perawat sesuai dengan tugas dan kewenangan masingmasing. Peran dokter dalam upaya penanggulangan HIV/AIDS pada kaum Gay, dokter berperan sebagai penyedia pelayanan kesehatan (care provider) dokter juga memilih jenis pengobatan (decision maker) yang tepat bagi anggota komunitas Gay sesuai dengan kebutuhan masing-masing pasein/klien. Dokter juga bertindak sebagai konselor (communicator) dengan memberikan konseling kepada kaum gay terkait dengan HIV/AIDS serta untuk senantiasa meningkatkan derajat kesehatan.

Peran perawat dalam menanggulangi HIV/AIDS pada kaum Gay, perawat memiliki peran sebagai care giver (pelaksana), perawat senantiasa memberikan asuhan keperawatan kepada pasien/klien dengan pemecahan masalah dengan metode dan proses keperawatan sesuai dengan kebutuhan masing-masing klien. Selain sebagai care giver, perawat juga berperan sebagai pendidik, dengan memberikan konseling kepada kaum gay terkait dengan HIV/AIDS sehingga asuhan keperawatan yang diberikan mendapatkan hasil yang baik.

Undang-Undang Nomor 29 tahun 2004 tentang Praktik Kedokteran pasal 39,. Pasal 39 yang menyatakan bahwa: "Praktik Kedokteran diselenggarakan berdasarkan pada kesepakatan antara dokter atau dokter gigi dengan pasien dalam upaya untuk pemeliharaan kesehatan, pencegahahan penyakit, peningkatkan kesehatan pengobatan penyakit dan pemulihan kesehatan."

11 Ta’adi, Hukum Kesehatan Sanksi dan Motivasi Bagi Perawat, edisi 2, Jakarta:EGC, 2012, hlm.14 
Dari penelitian yang saya lakukan di Puskesmas Halmahera, saat melakukan konseling pre test, dokter dan perawat tidak meminta persetujuan dari klien/pasien terkait dokter coas yang ingin mengikuti proses kegiatan VCT. Secara tidak langsung, dokter dan perawat tidak menjaga privasi klien atau pasien.

Tindakan dokter dan perawat yang tidak meminta persetujuan terlebih dahulu terkait dengan dokter coas atau orang yang ingin mengikuti VCT, bertentengan undangundang juga bertentangan dengan perjanjian yang sudah disepakati antara pihak puskesmas dan komunitas kaum gay, terkait dengan coas atau orang lain yang ingin melihat atau mengikutikegiatan VCT karena hal ini sangat berkaitan dengan privasi klien.

Dari penelitian yang dilakukan di Puskesmas halmahera dokter dan perawat terkait upaya penanggulangan HIV/AIDS pada kaum Gay, dokter dan perawat sudah melaksanakan tugasnya tetapi masih ada yang belum dilaksanakan sesuai dengan ketentuan-ketentuan yang terdapat dalam peraturan perundangan-undangan.

3. Faktor-faktor yang mempengaruhi peran dokter dan perawat dalam menanggulangi HIV/AIDS pada Kaum Gay.

\section{a. Faktor pendukung}

1) Fasilitas Kesehatan.

Ketersediaan fasilitas kesehatan merupakan sala satu faktor pendukung dalam upaya penanggulangan HIV/AIDS pada kaum Gay. Fasilitas kesehatan yang ada di Puskesmas Halmahera sudah baik, dan tersedia layanan untuk pemeriksaan HIV/AIDS secara komperehensif. Dengan adanya fasilitas kesehatan ini masyarakat yang di sekitar termasuk kaum gay dapat mengakses kesehatannya dengan mudah

2) Sumber daya kesehatan

Sumber daya kesehatan merupakan salah satu faktor pendukung dalam upaya penanggulanagan HIV/AIDS bagi kaum Gay. Hal ini sesuai dengan pasal 1 angka ke 2 UU Kesehatan: "Sumber daya dibidang kesehatan adalah segala bentuk dana, tenaga, perbekalan kesehatan, sediaan farmasi dan alat kesehatan, dan teknologi yang dimanfaatkan untuk menyelenggarakan upaya kesehatan, yang dilakukan oleh pemerintah, pemerintah daerah, dan/atau masyarakat". Peneliti menyimpulkan sumber daya kesehatan yang ada di Puskesmas Halmahera sudah sesuai dengan ketentuan yang ada pada UU Kesehatan.

3) Sarana dan Prasarana

Sarana dan Prasarana yang ada di Puskesmas Halmahera dalam upaya penanggulangan HIV/AIDS sangat memadai, hal ini ditandai dengan terdapatnya ruangan konseling yang aman yang bersifat rahasia, sehingga pasien merasa nyaman selama proses konseling berlangsung.

\section{b. Faktor penghambat}

1) Jumlah tenaga kesehatan (konselor) terbatas

Jumlah konselor yang ada di Puskesmas hanya terdapat dua orang. Hal ini menjadi permasalah, dikarenakan jumlah pasien yang melakukan VCT semakin bertambah 
2) Pasien tidak membuka diri

Dalam melakukan upaya penanggulangan HIV/AIDS pada kaum Gay, tidak semua anggota komunitas Gay membuka diri mengenai keadaan yang mereka hadapi, sebagian dari mereka cenderung tertutup. Hal ini membuat dokter dan perawat sulit untuk melakukan konseling terhadap pasien.

\section{KESIMPULAN}

1. Peraturan tentang Peran Dokter dan Perawat dalam Menanggulangi HIV/AIDS pada Kaum Gay

Peraturan tentang peran dokter dan perawat dalam menanggulangi HIV/AIDS pada Kaum Gay diatur dalam beberapa dasar hukum antara lain: Undang-Undang Dasar 1945, Undang-Undang Nomor 39 tahun 1999 tentang Hak Asasi Manusia, UndangUndang Nomor 29 tahun 2004 tentang Praktik Kedokteran, Undang-Undang Nomor 36 tahun 2009 tentang Kesehatan, Undang-Undang Nomor 36 tahun 2014 tentang Tenaga Kesehatan, Undang-Undang Nomor 38 tahun 2014 tentang Keperawatan, Peraturan Menteri Kesehatan Nomor 21 tahun 2013 tentang Penanggulangan HIV dan AIDS, Peraturan Menteri Kesehatan Nomor 74 tahun 2014 tentang Konseling dan Tes HIV, dan Peraturan Daerah Kota Semarang Nomor 4 tahun 2013 tentang Penaggulangan $\mathrm{HI}$ dan AIDS.

\section{Pelaksanaan Peran dokter dan Perawat dalam Menanggulangi HIV/AIDS pada Kaum Gay}

Pelaksanaan peran dokter dan perawat dalam menanggulangi HIV/AIDS pada kaum Gay sudah dilaksanakan, tetapi masih belum dilaksanakan sesuai dengan ketentuan yang ada diperaturan perundang-undangan. Peran dokter dalam upaya penanggulangan HIV/AIDS pada kaum Gay, dokter berperan sebagai penyedia pelayanan kesehatan (care provider) dokter juga memilih jenis pengobatan (decision maker) yang tepat bagi anggota komunitas Gay sesuai dengan kebutuhan masingmasing pasein/klien. Dokter juga bertindak sebagai konselor (communicator) dengan memberikan konseling kepada kaum gay terkait dengan HIV/AIDS serta untuk senantiasa meningkatkan derajat kesehatan.

Peran perawat dalam menanggulangi HIV/AIDS pada kaum Gay, perawat memiliki peran sebagai care giver (pelaksana), perawat senantiasa memberikan asuhan keperawatan kepada pasien/klien dengan pemecahan masalah dengan metode dan proses keperawatan sesuai dengan kebutuhan masing-masing klien. Selain sebagai care giver, perawat juga berperan sebagai pendidik, dengan memberikan konseling kepada kaum gay terkait dengan HIV/AIDS sehingga asuhan keperawatan yang diberikan mendapatkan hasil yang baik.

\section{Faktor-faktor yang Mempengaruhi peran dokter dan perawat dalam menanggulangi HIV/AIDS pada Kaum Gay}

Faktor pendukung dalam melakukan upaya penaggulangan HIV/AIDS pada Kaum Gay adalah tersedianya fasilitas kesehatan, sumber daya kesehatan dan sarana dan prasarana yang memadai. Faktor penghambat dalam melakukan upaya penaggulangan HIV/AIDS pada kaum Gay adalah kurangnya tenaga kesehatan sebagai konselor HIV/AIDS serta kurang adanya keterbukaan diri dari kaum Gay. 


\section{SARAN}

\section{Bagi Tenaga Kesehatan (dokter dan Perawat)}

Bagi tenaga kesehatan yaitu dokter dan perawat, untuk senantiasa memberikan pelayanan yang bermutu dan komperehensif sesuai dengan tugas dan kewenangan masing-masing, serta dalam melakukan VCT terhadap kaum Gay untuk senantiasa meminta persetujuan dari pasien apabila ada yang ingin mengikuti atau melihat proses VCT. Dokter dan perawat harus mengembangkan dan meningkatkan ilmu pengetahuan dengan mengikuti pelatihan-pelatihan terkait dengan HIV/AIDS

\section{Bagi Kaum Gay}

Kaum Gay di harapkan untuk tetap meningkatkan derajat kesehatan, dengan memeriksakan diri kepelayanan kesehatan khususnya terkait dengan HIV/AIDS. Bagi kaum Gay yang tidak terinfeksi HIV untuk tetap menjaga perilaku seks yang aman dan tidak bergonta ganti pasangan seks. Sedangkan bagi kaum Gay yang terinfeksi HIV untuk selalu mengkonsumsi ARV.

\section{Bagi Peneliti Selanjutnya}

Diharapkan agar peneliti selanjutnya dapat melanjutkan penelitian ini melalui sudut pandang yang berbeda serta dapat menemukan faktor-faktor yang lain yang lebih rinci terkait penanggulangan HIV/AIDS pada Kaum Gay.

\section{DAFTAR PUSTAKA}

Afriko, Joni. 2016. Hukum Kesehatan (Teori dan Aplikasinya). Bogor: In Media.

Ali, Zainudin. 2016. Metode Penelitian Hukum. Jakarta: Sinar Grafika

Adi, Rianto. 2005. Metode Penelitian Sosial dan Hukum. Jakarta: Granit

Achmadi, H, Abu \& Cholid Narbuko. 2015. Metode Penelitian. Jakarta : Bumi Aksara

Andareto, Obi. 2015. Penyakit Menular di Sekitar Anda. Jakarta: Pustaka Ilmu Semesta

Aziz, Safrudin. 2017. Pendidikan Seks Perspektif Terapi Sufistik bagi LGBT. Kendal: Ernest

Dewi, Prima \& Hardianah. 2014. Virologi mengenal virus penyakit dan pencegahannya. Yogyakarta: Nuha Medika

Djoerban, Zubairi.1999. Membidik AIDS Ikhtiar Memahami HIV dan ODHA. Yogyakarta: Galang Press.

Fulthoni,dkk. 2009. Memahami Diskriminasi Buku Saku Untuk Kebebasan Beragama. Jakarta: The Indonesian Legal Resource Center (ILRC)

Gaffar, La, Ode, Jumadi. 1999. Pengantar Keperawtan Profesional. Jakarta: EGC

Gallant, Joel. 2010.100 Tanya Jawab mengenai HIV dan AIDS. Jakarta: PT indeks.

Gunawan, Imam. 2016. Metode Penelitian Kualitatif Teori dan Praktik. Jakarta: Bumi Aksara

Hardjodisastro, Daldiyono. 2006. Menuju Seni Ilmu Kedokteran, Jakarta: Gramedia Pustaka Utama.

Hanintijo, Roni.1995. Studi Hukum Dan Masyarakat. Bandung: PT Alumni 
Hippocampus. 2012. Medical Etichs \&Law. MISC

Marmi. 2013.Kesehatan Reproduksi. Yogyakarta: Pustaka Pelajar

Muninjaya, A.A. Gde. 1995.AIDS Dikenali Untuk Dihindari. Denpasar: FK. Universitas Udayana.

Nasir, Moh. 2011. Metode Penelitian. Jakarta: Gralia Indonesia.

Nasution, Bahder, Johan. 2008. Metode Penelitian Ilmu Hukum. Bandung: Mandar Maju

Notoatmojo, Soekidjo. 2002. metode penelitian kesehatan. jakarta: rineka cipta

.2010. Etika \& Hukum kesehatan. Jakarta: PT Rineka Cipta.

- - Promosi Kesehatan Teori dan Aplikasi: Jakarta: Rineka Cipta

Noviana, Nana. 2016. Konsep HIV/AIDS Seksualitas dan Kesehatan Reproduksi. Jakarta: Trans Info Media

Nurbana, Erlies \& Septiana H.Salim Hs. 2014. Penerapan Teori Hukum pada Penelitian Disertasi dan Tesis. Jakarta: Raja Grafindo Persada

Praptianingsih, Sri. 2006. Kedudukan Hukum Perawat dalam Upaya Pelayanan Kesehatan di Rumah Sakit. Jakarta: PT Raja Grafindo Persada

Sadarjoen, Sawitri, Supardi. 2005. Bunga Rampai Kasus Gangguan Psikosekual. Bandung: PT Refika Aditama

Soeparto, Pitono, dkk. 2006. Etik Dan Hukum Dalam Bidang Kesehatan, edisi kedua. Surabaya: Airlangga University Press.

Sudarma, Momon. 2008. Sosiologi Untuk Kesehatan. Jakarta: Salemba Medika.

Suhardono, Edy. 1994. Teori Peran: Konsep, derivasi dan Implikasinya. Jakarta: Gramedia Pustaka Utama

Ta'adi. 2012. Hukum Kesehatan Sanksi dan Motivasi Bagi Perawat, edisi 2. Jakarta: EGC

Yeo, Anthony. 1999. Konseling Suatu Pendekatan Pemecahan Masalah. Jakarta: PT BPK Gunung Mulia.

\section{Peraturan Perundang-Undangan}

RI, Undang-Undang Dasar Tahun 1945

RI, Undang-Undang Nomor 39 Tahun 1999 Tentang Hak Asasi Manusia

RI, Undang-Undang Nomor 29 Tahun 2004 Tentang Praktik Kedokteran

Rl, Undang-Undang Nomor 36 Tahun 2009 Tentang Kesehatan

RI, Undang-Undang Nomor 36 Tahun 2014 Tentang Tenaga Kesehatan

RI, Undang-Undang Nomor 38 Tahun 2014 Tentang Keperawatan

RI, Permenkes Nomor 21 Tahun 2013 Tentang Penanggulangan Hiv dan AIDS

RI, Permenkes Nomor 74 Tahun 2014 Tentang Pelaksanaan Konseling dan Tes HIV 
Jurnal

Nirmala Herlani, Emmy Riyanti, Bagoes Widjanarko:, Gambaran Perilaku Seksual Berisiko HIV/AIS Pada Pasangan Gay, 2016, Jurnal Kesehatan Masyarakat Volume 4, No. 3, Juli 2016, , https://media.neliti.com/media/publications/105739-ID-gambaranperilaku-seksual-berisiko-hiv-a.pdf diakses tanggal 15 Oktober 2017

Yogestri Rakhmahappin dan Adhyatman Prabowo, kecemasan sosial kaum homoseksual Gay dan Lesbian, 2014, Jurnal Ilmiah Psikologi Terapan Universitas Muhammadiah Malang, Volume 02, no.2, Tahun 2014, ISSN:2301-8267.

http:/www.google.com/url?sa=t\&rct=j\&q=\&esrc=s\&source=web\&cd=1\&cad=rj a\&uact $=8$ \&ved=0ahUKEwi6xIOk3tbZAhXHPo8KHYdqDv4QFggpMAA\& url=http\%3A\%2F\%2Fejournal.umm.ac.id\%2Findex.php\%2Fjipt\%2Farticle \%2Fdownload\%2F1997\%2F2099\&usg=AOvVaw2ZNaW2WqIFZ70bLvV9 ED5X,

Referendi Internet

Chapter II. repository. usu.ac.id. diakses tanggal 6 februari 2018, pukul 20.09 WIB

FX Suharto. 2013. Nilai Sentral Kedokteran Keluarga. https://willimhaveyou.files.wordpress.com/2013/12/nilai-sentral-kedokterankeluarga.pdf, diakses tanggal 30 Oktober 2017

Komisi Penangnggulangan AIDS Pusat Jawa Tengah, Kondisi HIV dan AIDS di Jawa Tengah 1993 s/d September 2015, http://dinus.ac.id, diakses tanggal 15 Oktober 2017

Laporan Perkembangan HIV-AIDS dan penyakit Infeksi Menular Seksual Triwulan 1 tahun 2017.www.aidsindonesia.or.id. diakses tanggal 16 Oktober 2016

Susan Wira Anggraeni, Perilaku dan Gaya Hidup Komunitas Gay, 2013, http://digilib.unila.ac.id/269/ diakses tanggal 28 Oktober 2017

Wikipedia, https://id.wikipedia.org/wiki/Gay, diakses tanggal 29 Oktober 2017 